\title{
New Trends in Pesticide Residues Control and Their Impact on Soil Quality and Food Safety
}

\author{
Adriana Mariana Borş, Irina Meghea and Alin Gabriel Borş
}

Additional information is available at the end of the chapter

http://dx.doi.org/10.5772/48661

\section{Introduction}

The concept of sustainable development represents the totality of forms and methods for the socio-economic development, whose foundation is primarily to ensure a balance between the socio-economic systems and the natural capital.

This concept has become, bringing into focus the complex relationship between development and environment, the quality of human activity and consciousness, of present and future.

The increasing needs of food as a result of world population growth have led to intensive use of chemicals, particularly of fertilizers and pesticides. Despite of the beneficial role on increasing production, some pesticides have been shown to have a negative effect on human health by means of bioaccumulation as a result of residues persistence in food.

Nutrition trends, especially in recent decades have turned to integral grains and unrefined flours with a high nutrient content and also to increase the fiber weight in the diet, with beneficial effects on the human health, thus leading to increased consumption of such products with diversified sorts of integral bread grains.

The importance of these varieties is primarily derived from their chemical composition, high contents of proteins and essential amino acids, mineral substances and lipid compounds, and also from the fact that, in the production process, they do not require large inputs, are not demanding from the conditions of cultivation, fertilization, tolerance to diseases and pests, and can survive at harsh climate.

In this chapter the correlation parameters of grain quality and safety of biological factors, climate (in terms of climatic influence) and technological parameters will be studied in order to identify potential safety concerns of persistent pesticide residues remained in cereals after subjecting them to different treatments on vegetation under cultivation technology. 
To follow-up on the evolution status of soil fertility, the application of measures to improve its physiological and biochemical properties is need, as well as the rational use of the chemicals applied in order to maintain soil productivity on the required parameters.

As part of the scientific and technical data, aspects on the agrochemical and biological characteristics of soil are of high importance to the rational application of fertilizers and pesticides. It is also necessary to know the basic principles of micro-organism life in soil, as well as knowledge of the biochemical processes that ensure the fertility of cultivated and uncultivated land.

Soil pollution can be of diverse nature: physical, chemical, biological and radioactive. It can be quantified by assessing the qualitative and / or quantitative reduction of agricultural production as compare to normal situation. Among the above mentioned pollution types, the most frequent and harmful are those caused by the use of fertilizers and pesticides.

High toxicity of some plant protection chemicals applied in various forms (powder, dust, granules, capsules, solutions, suspensions, aerosols, foams, gas, steam, paste) may cause direct poisoning of plants and animals, generating changes and disturbances of equilibrium. The pesticides penetrating the plants or into the soil undergo chemical reactions and biochemical transformations on the plant surface or inside their tissues.

On the other hand, pesticides in the soil or subsoil are absorbed through complex processes such as: transfer of load, ionic exchange, and hydrophobic bonds. Soil particles, by means of clay-humic complex, represent an adequate support for both pesticides adsorption and for some of their degradation byproducts, the adsorptive capacity depending on soil texture.

The effect of pesticides on soil microbiological activity was studied by examining microorganism response after the application of different doses of insecticides, fungicides and herbicides. To certify the statistical dependence of the numerical variation of populations of micro-organisms, enzyme activity and soil chemical properties, correlations have been performed among the values of these indices.

Research has continued and the response of soil micro-organisms was examined, following the application of doses of pesticides, according to the requirements of application recommended. Thus, it was found that, in compliance with pesticide application dose, soil microorganisms are not affected.

Biological properties of soils, such as enzymatic activity and the total number of microorganisms in the soil, serve as a tool for assessment of soil quality change under the influence of various agrochemical processes, regarding the state of fertility for the diagnosis and certification of influence of the application of chemical fertilizers and pesticides on the global biological activity of soil. Moreover, it is important to know the activity of microorganisms and their seasonal variation and to quantify their involvement in reducing the residual effect of pesticides.

Research of chemical fertilizers influence on physical, chemical and biological soil indices can offer the possibility to find practical solutions to prevent on the one hand, the 
emergence of negative changes in soil chemistry and, on the other hand, to intervene efficiently for the optimal recovery of agrochemical indicators.

\section{Influence of chemical fertilizers and pesticides on soil properties and ecological implications}

Environmental protection in agricultural production is of particular importance for the national economy and especially to ensure an optimal framework of social life in rural and urban communities. In recent decades there has been a continuous chemicalization of agriculture to maintain a high level of crops, while obvious depletion of soil nutrients in natural substances. An important place in agricultural process is occupied by the use of a wide range of pesticides. They are particularly useful to solve problems for which they were created and applied.

However, their accumulation in soil, flora and fauna, and uncontrolled migration in the environment of residues resulted from the recovery processes can produce some hazardous effects on both plants and the ecosystem as a whole. In this case, accumulation and uncontrolled migration in soil and groundwater of pesticides can cause significant disturbances to the environmental factors.

Fertilization with chemical fertilizers and pesticide treatments must take into account soil and climatic conditions to prevent some harmful phenomena on plant production.

Plant nitrate pollution is caused by excess mineral nitrogen applied as nitric and has a harmful action on living organisms.

Forage plants (ryegrass, cocksfoot) and especially feed grains (green mass) have a higher concentration of nitrates. Moreover, many plants with thick stems (sunflower, crucifers) accumulate nitrates. Root crops contain more nitrates in leaves than in roots. Legumes do not normally accumulate nitrates. Pollution plant products are made through absorption by plants of pesticides in soil, where they are found in excessive amounts. Absorption intensity depends on the nature of pesticides, plant species and soil type.

Plant pollution by nitrates and pesticides is made through their absorption from the soil, at their rate, the forage plants are consumed by animals and thus the animal products are contaminated (meat, milk, etc.).

Maintaining the maximum allowable levels of nitrates, pesticides and heavy metals in soil can be done by preventive measures such as reducing industrial pollutants, control of wastewater used for irrigation, rational use of manure from industrial growth of pigs, cattle and poultry, etc.

The main problems involved in the dynamics of pesticides in soil (adsorption, volatilization, absorption, degradation, migration, accumulation, etc.) are the subject of extensive laboratory and field studies of both theoretical and experimental profile. In recent years, theoretical and experimental investigations have contributed to highlighting the results of certain scientific and practical value. These results were reflected in the following areas: 
- $\quad$ analysis of the main factors determining migration of pesticides in soil;

- setting specific coefficients based on the influence of different pedoclimatic factors on the processes involving pesticides in physical - chemical and biological complex of soil;

- development of criteria for building a forecasting model for soil pollution; define model forecast for pollution of various characteristic types of soil;

- development of criteria for building a forecasting model of groundwater pollution, define model forecast for groundwater pollution in static and dynamic regims;

- qualitative and quantitative determination of coefficients specific to pollution process (diffusion, retention, degradation, etc.).

\subsection{Risk assessment of pesticide pollution on soil microbiological activity}

Research was conducted to examine the response of soil microorganisms, as a result of application of specific pesticide doses, according to the recommended requirements of application. Each soil sample was treated with one of the following pesticides at recommended dosages: insecticide at the rate of $0,0025 \mathrm{~g}$, fungicide at the rate of $0,01 \mathrm{~g}$ and herbicide at the rate of $0,01 \mathrm{ml}$. Thus, it was found that, in compliance with pesticide application doses, microorganism life in soil is not significantly affected.

\begin{tabular}{|c|c|}
\hline Days of incubation sample & Total number of germs (T.N.G.) \\
\hline $\begin{array}{c}\text { Control } \\
0 \\
\text { insecticide }\end{array}$ & $\begin{array}{l}6.8 \times 10^{6} \\
6.8 \times 10^{6}\end{array}$ \\
\hline $\begin{array}{c}\text { Control } \\
5 \\
\text { insecticide } \\
\end{array}$ & $\begin{array}{l}1.9 \times 10^{7} \\
4.1 \times 10^{7}\end{array}$ \\
\hline $\begin{array}{c}\text { Control } \\
10 \\
\text { insecticide }\end{array}$ & $\begin{array}{l}3.2 \times 10^{7} \\
5.4 \times 10^{7}\end{array}$ \\
\hline $\begin{array}{c}\text { Control } \\
15 \\
\text { insecticide }\end{array}$ & $\begin{array}{l}1.1 \times 10^{6} \\
1.4 \times 10^{7}\end{array}$ \\
\hline $\begin{array}{c}\text { Control } \\
20 \\
\text { insecticide }\end{array}$ & $\begin{array}{l}0.6 \times 10^{6} \\
4.9 \times 10^{6}\end{array}$ \\
\hline
\end{tabular}

Table 1. Effect of insecticide on the number of total microorganisms per gram of dry soil

As shown, normal dosage of insecticide applied to soil has little effect on microflora at the 10th day of incubation, with no increase in the total number of germs as compared to control. In the following days of incubation a small increase in the number of microorganisms in soil treated is observed as compare to control. This shows that microorganisms are able to multiply in the presence of insecticide. 


\begin{tabular}{|c|c|}
\hline Days incubation samples & Total number of germs (T.N.G.) \\
\hline witness & $\begin{array}{l}6.8 \times 10^{6} \\
6.8 \times 10^{6}\end{array}$ \\
\hline $\begin{array}{c}\text { fungicide } \\
\text { witness } \\
5\end{array}$ & $3.1 \times 10^{7}$ \\
$4.7 \times 10^{7}$ \\
fungicide & $3.8 \times 10^{7}$ \\
\hline witness & $4.9 \times 10^{8}$ \\
10 & $2.3 \times 10^{6}$ \\
fungicide & $1.9 \times 10^{8}$ \\
\hline witness & $1.2 \times 10^{6}$ \\
15 & $4.4 \times 10^{7}$ \\
\hline fungicide & \\
\hline witness &
\end{tabular}

Table 2. Effect of fungicide on the number of total microorganisms per gram of soil

The number of germs indicates that soil on which the fungicide was applied contains microorganisms capable to metabolise this fungicide. In reference soil a decrease in the number of microorganisms during the incubation was observed.

\begin{tabular}{|c|c|}
\hline Days of incubation & Total number of germs (T.N.G.) \\
\hline Control & $7.5 \times 10^{6}$ \\
0 & $7.5 \times 10^{6}$ \\
herbicide & $1.9 \times 10^{5}$ \\
Control & $4.4 \times 10^{7}$ \\
5 & $3.5 \times 10^{6}$ \\
herbicide & $4.9 \times 10^{7}$ \\
\hline Control & $7.9 \times 10^{6}$ \\
10 & $2.7 \times 10^{7}$ \\
herbicide & $6.4 \times 10^{6}$ \\
Control & $2.0 \times 10^{7}$ \\
\hline herbicide & Control \\
20 & \\
\hline
\end{tabular}

Table 3. Effect of SDMA herbicide on the number of total microorganisms per gram of dry soil

In soil treated with herbicide the microorganisms can grow and multiply.

On the whole, one can remark that normal doses of insecticides, fungicides and herbicides have little effect on total number of germs in the first incubation period, but afterword there 
is an increase. Therefore, microorganisms are able to multiply in the presence of insecticides and fungicides, while in the presence of herbicides they are multiplied rapidly.

It is important to know the activity of microorganisms and their seasonal variation due to their involvement in reducing the residual effect of pesticides.

Note: Decis Mega 50 EW (emulsion in water), Substance active: deltametrin $50 \mathrm{~g} / 1$

Pyrethroid insecticide for pest control in wheat, apple, cherry, plum, apricot, peach, cabbage, eggplant, tomato, lettuce, potato, rapeseed, vines, corn, sunflower, sugar beet.

Wheat: using the dose of 0.151 / ha in 300-400 liters of water to combat bedbugs cereals (Eurygaster integriceps) Balos beetle (Lema melanopa) and red worm straw (Haplodiplosis marginata)

Apple: $0.0125 \%$ (0.187 1 / ha in 1500 liters of water) to combat worm moth (Cydia pomonella). $0.015 \%$ (0.225 1 / ha in 1500 liters of water) for aphids (Aphis trees), skin fruit moth (Adoxophyes reticulana), San Jose Scale (Quadraspidiotus perniciosus)

Cabbage: $0.02 \%$ (0.12 1 / ha in 600 liters water) to combat headed eagle (Mamestra brassicae) L1-L3 larvae, aphids (Brevicoryne brassicae)

Beet sugar: $0.151 /$ ha to fight ladybug leaves of maize (Tanymecus dilaticollis), beet flea (Chaetocnema tibialis) and ladybug beet (Bothynoderes punctiventris).

Aliette 80 WG(water dispersible granules), Substance active: aluminum fosetyl $800 \mathrm{~g} / \mathrm{kg}$

Systemic fungicide for disease control in vegetables, fruit trees, hops.

Apple, pear, quince: $0.3 \%$ for fire fighting of rozaceelor bacterial (Erwinia amylovora).

Cucumber: $0.2 \%$ (2 kg / ha) to control blight (Pseudoperonospora cubensis)

Hops: $0.2 \%$ ( $4 \mathrm{~kg} /$ ha in 2000 liters of water) to combat blight (Pseudoperonospora humuli).

SDMA-is a systemic herbicide for weed control in wheat, corn and grass.

Application rate of $1 \mathrm{~L} /$ hectar in 250-350 liters of water.

\section{Methods for identifying pesticide residues}

\subsection{Determination of compounds of interest}

Achieving quality parameters depends on several factors such as genetic potential quality of the cultivated variety which materializes only in terms of ensuring all the elements of culture technology, taking into account the natural and climatic background of the area.

Nutritional value of proteins in certain grains (synthesis species of rye and wheat, a variety of higher production potential and adaptability as compared to other cereals) is higher than that of wheat. Thus, to improve the quality parameters of bakery products the utilization of these types of cereals has been studied, choosing a species with high resistance to low temperatures, and using modern methods of investigation in order to determine the content of pesticides in such cereal species. For cereals investigated, certain quality and safety parameters have been correlated with biological, climatic (in terms of climate impact) and technologic factors. 
In specific phenological/evolutionary moments important for vegetation period various combinations of treatments with foliar fertilizer (phosphorus or nitrogen), fungicides, insecticides and herbicides have been applied.

In order to determine the compounds of interest regarding the identification of pesticide residues in commercial products the active substances present in treated grain samples have been analyzed. Treatments applied to these grain varieties under study aimed at combating pests, fungi that cause plant diseases and weeds that destroy crops.

Quality assessment of bread-making grains was based on measurements performed by standard physico-chemical methods to characterize the integrity and quality of cereal species under study, quality of meal mixtures and quality of the finished product made from whole wheat.

\subsection{Choosing QuEChERS extraction method}

Extraction method chosen is QuEChERS method suitable for pesticide determination in dry samples as whole wheat, wheat flour and bran according to the literature and based on solid phase extraction, with the advantage of retaining co-extracted substances in the extract and pesticide releasing. The method adapted to wheat matrix used to determine pesticide residues is highly competitive for GC-MS analysis and is based on the following reasons: time savings, lower volumes of solvents, validated in analytical conditions of repeatability, reproducibility, specificity and accuracy.

\subsection{Determination of performance parameters}

Determination of pesticide residues in food matrix in compliance with regulations in force laid down determination of performance parameters of the method (linearity, repeatability, reproducibility, accuracy and recovery coefficient), both for standard methods and those with small improvements.

For qualitative determination a series of callibration solutions has been injected into gas chromatograph in order to identify retention times for each compound of interest based on chromatograms obtained by using the SCAN module. This SCAN identification of compound has been performed based on NIST library spectra. This involves determination of the mass spectrum from GC / MS analysis of pesticide standard together with the mass spectra of possible compounds found in the spectra library.

For quantitative determination in SIM mode a calibration curve of analyzed compounds was drawn and thus the concentration range was established for which linearity was established. As the concentration range of samples is fairly wide two different calibration curves have been chosen, as follows:

- $\quad$ low concentration range: 0.02 ppm - 0.2 ppm;

- $\quad$ high concentration range: $0.2 \mathrm{ppm}-1.5 \mathrm{ppm}$ 
To highlight the method precision - repeatability and reproducibility, determinations were performed simultaneously on pesticide residues, establishing average standard deviation (RSD\%).

To verify the method accuracy, we determined the recovery coefficient $( \pm C R)$, for two compounds analyzed (eg amidosulfuron, tebuconazole), achieving thus a sample enriched with standard concentrations.

\subsubsection{Relationship between pesticide residues content detected and some quality parameters of grain studied}

Achieving increased production per unit area and obtaining appropriate quality agro-food products is a constant concern of specialists. Food value of agricultural products can be determined both by physical and chemical methods. Research conducted for chemical testing of wheat quality is refered to the protein content and quality, but also to the ripeness and freshness of the finished product.

Analysis of the results obtained by combining the two methods best reflects the technological indices of wheat flour. Thus, one can track the contribution of various factors (climate - climatic conditions of experimental years 2008 to 2011, biological - and technological species - fertilization and vegetation treatments) to achieve qualitative characteristics of cereals in the study, each factor having a specific influence on grain quality. Percentage estimation of these factors is shown in the table bellow.

\begin{tabular}{|c|c|c|c|c|c|}
\hline $\begin{array}{c}\text { Factor/ } \\
\text { Parameter }\end{array}$ & $\begin{array}{c}\text { Climatic } \\
\text { conditions }\end{array}$ & $\begin{array}{c}\text { Species } \\
\text { type }\end{array}$ & Treatment & Interactions & Fertilization \\
\hline $\begin{array}{c}\text { Mass/storage } \\
\text { Volume (kg/hl) }\end{array}$ & 57 & 33 & 5 & 3 & 2 \\
\hline Protein Content, \% & 76 & 6 & 1 & 5 & 12 \\
\hline Sedimentation Index, \% & 49 & 2 & - & 6 & 43 \\
\hline Wet gluten, \% & 84 & 8 & 1 & 3 & 4 \\
\hline Distortion Index, mm & 57 & 15 & - & 3 & 23 \\
\hline Gluten index, \% & 82 & 7 & 1 & 3 & 5 \\
\hline Fall index, sec & 24 & 39 & - & 37 & - \\
\hline
\end{tabular}

Table 4. Contribution of various factors on qualitative characteristics of cereals

A critical role is played by knowledge of the relationship among the main quality parameters of grain species studied. In this respect, the strongest influence on the quality indicators is given by the species $x$ year interaction (climatic conditions), then species $x$ fertilization, while there is an insignificant influence from species $x$ treatment interaction.

Since the factor "year", from climatic point of view, had the most important influence in achieving quality parameters (according to variant analysis), for better highlighting the quality of grain species, the influence of environmental conditions have been analysed, as it was identified by the species $x$ year interaction (in terms of climate) for the main quality parameters. 
The genetic potential is valorized only by a proper fertilization and at given levels of precipitations and normal temperatures.

Analyzing the evolution of quality parameters as function on fertilization dose, the control sample and sample of species analyzed, one can conclude that additional fertilization affects the following quality parameters: ash, protein, sugars, total fibers, cellulose enzyme activity and energetic value. In terms of appearance, fertilization significantly affects the volume of finished product.

Bread volume is related to its form which is obtained by determining the ratio of product height $(\mathrm{H})$ and diameter (D). The ratio $\mathrm{H} / \mathrm{D}$ allows characterizing aspects referring to product volume and shape.

As referring to agro-fund, the results highlight the crucial role of the additional dose of fertilizer in terms of parameters characterizing the finished product quality.

Providing additional dose of fertilizer correlated with favourable weather conditions, the ratio grain: wheat may reach up to $70 \%$.
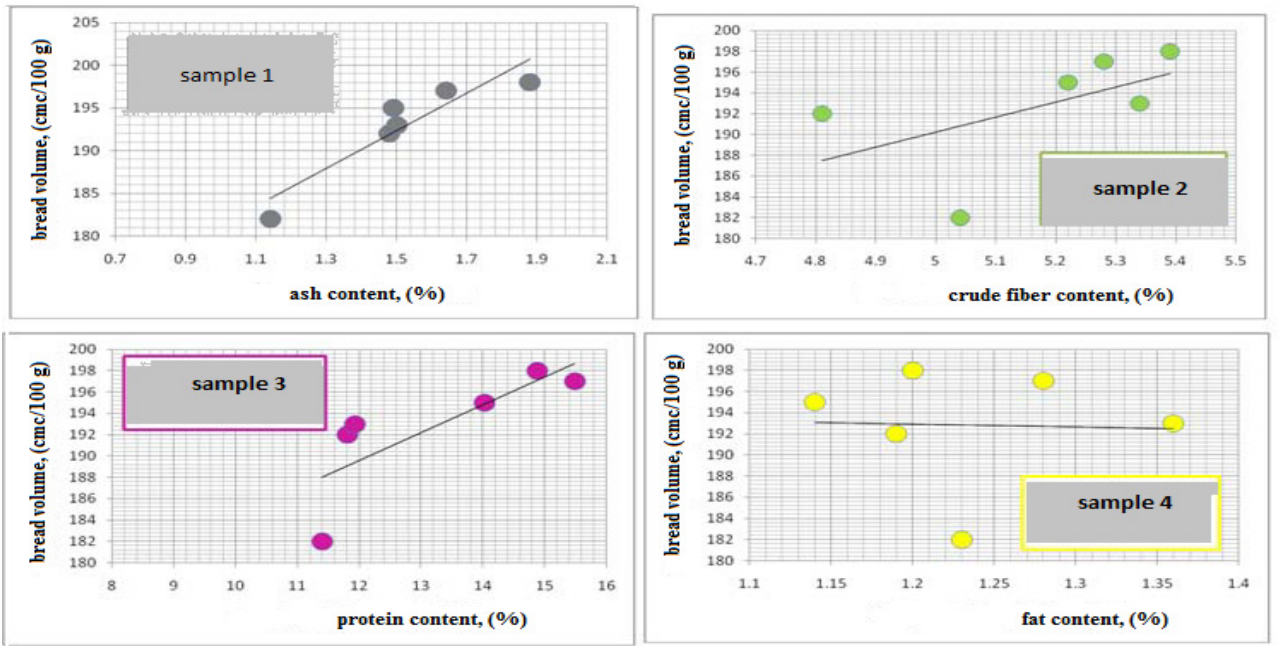

Figure 1. Correlations among some quality parameters of flour and bread volume of finished product

Volume change of finished bakery products (bread) is determined by the variation of content as follows: ash $(80-85 \%)$, starch $(70-75 \%)$, protein $(60-65 \%)$, sugar $(35-40 \%)$, fiber and energy value $(25-30 \%)$ and it is not influenced by the fat content $(0 \%)$. There is a strong link among the volume of finished bakery products and ash, starch or protein of interest, and a connection of medium interest between the sugar content and the volume of finished product bakery (bread), among the fiber content, energy value and volume. There is no association between fat content and bread volume, these variables being uncorrelated. 


\subsection{Determination of pesticides by modern methods of investigation}

Protocol requires the extraction of pesticides using acetonitrile and extract purification using solid phase extraction (D-SPE) on a C18 column as sorbent material (octadecyl), followed by gas chromatographic determination coupled with mass spectrometry (GC-MS).

The compounds identified in samples containing pesticide residue are: amidosulfuron, $(0.01$ - $0.04 \mathrm{mg} / \mathrm{kg})$, propioconazol $(0.03 \mathrm{mg} / \mathrm{kg})$, tebuconazole $(0.11-0.19 \mathrm{mg} / \mathrm{kg})$.

Variations in pesticide content and comparison with pesticide regulations on MRLs (maximum residue limit), and relative proportions of the analyzed samples are presented in the following figures:

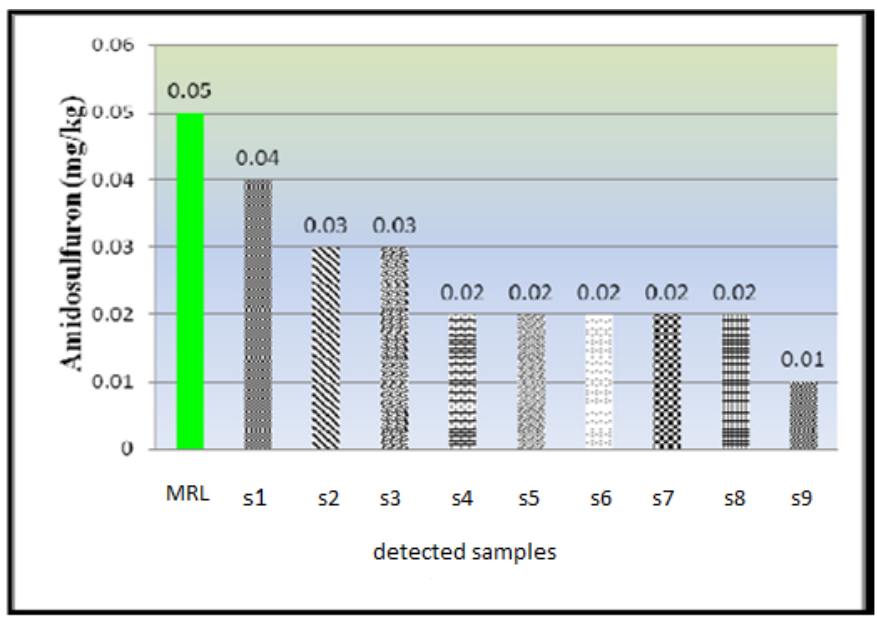

Figure 2. Amidosulfuron content as compared with MRL

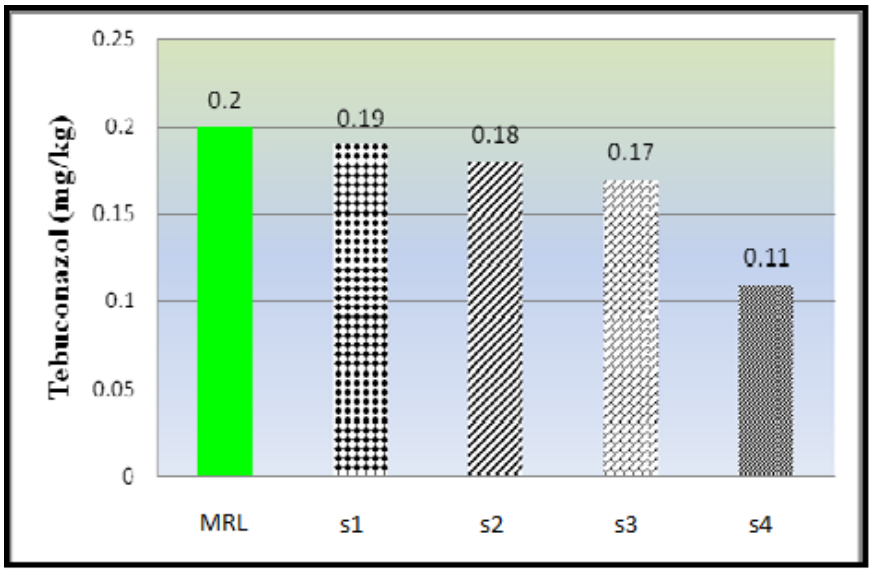

Figure 3. Tebuconazol content copared with MRL 
The relationship between some quality parameters and content of pesticide residues detected allows explain to what extent this pesticide content, even it is bellow the maximum residual limit (MRL), can be influenced by some quality parameters of grain analysed. To measure the intensity of these relationships between pesticide residues and various quality parameters, the linear correlation coefficient was calculated.

Analyzing the data using the regression equations represented in Fig. 4, one can say that there are insignificant correlations between amidosulfuron content and moisture $(r=0.24)$, protein content $(\mathrm{r}=0.35)$ or gluten content $(\mathrm{r}=0.14)$ and a moderate correlation between amidosulfuron content and mass per storage volume $(r=0.54)$.
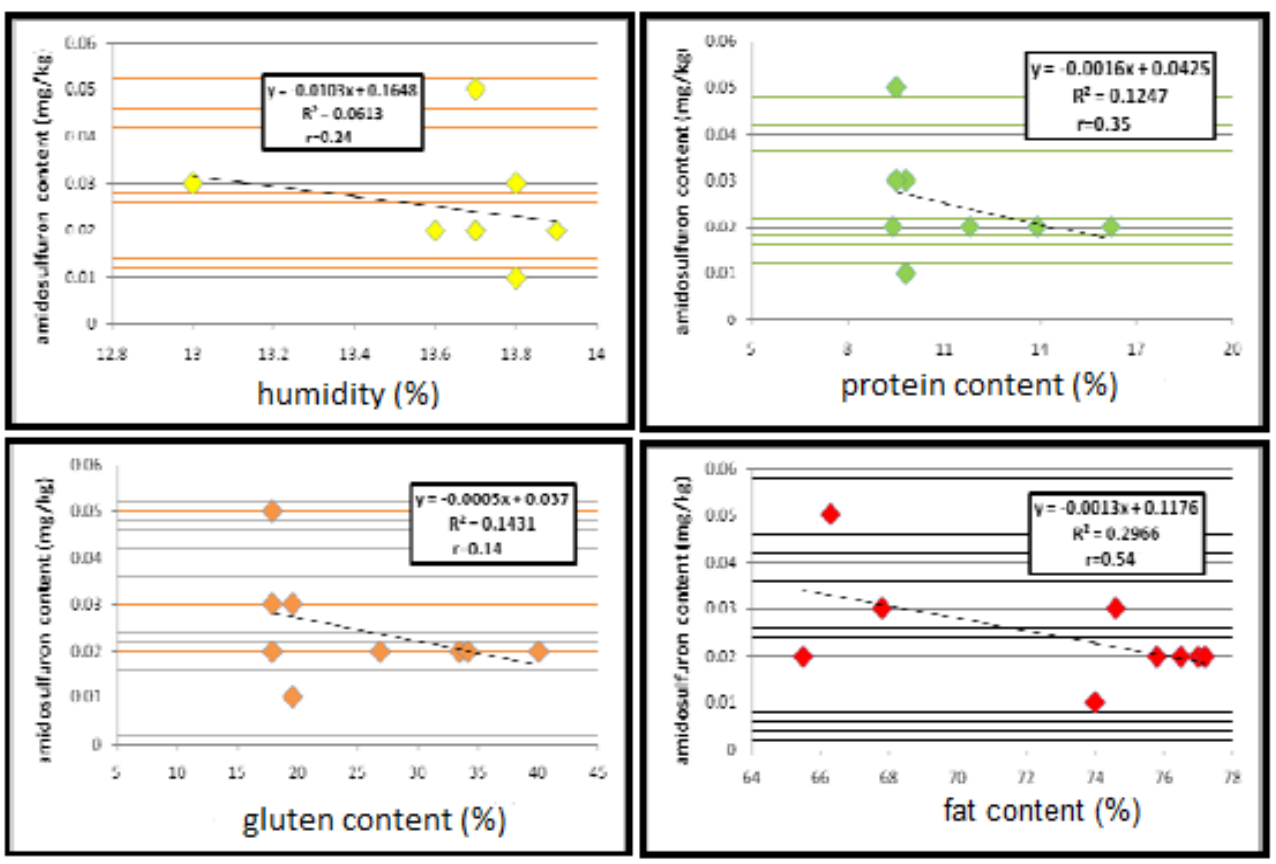

Figure 4. The relationship between some parameters of quality and content amidosulfuron

\section{Methods for organochlorine insecticides analyses in soil, water, plants and their monitoring}

\subsection{Quantitative determination of organochlorine insecticide residues by GC- ECD and GC-MS techniques}

For qualitative and quantitative organochlorine insecticides determination in soil two methods for multi-residues analyses have been applied: gas-chromatography with electron 
capture detector (GC-ECD) and gas-chromatography with mass spectrometer detector (GCMS). Standard stock solution of $1000 \mathrm{mg} / \mathrm{L}$ (19 organochlorine insecticides) has been prepared from which dilutions up to $1 \mathrm{mg} / \mathrm{L}$ were made.

Standards solutions for calibration curve were prepared in the range of $0.025 \mathrm{mg} / \mathrm{L}-$ $0.5 \mathrm{mg} / \mathrm{L}$ with intermediate points of $0.05 ; 0.1$ and $0.25 \mathrm{mg} / \mathrm{L}$, and were injected into GCECD.

\begin{tabular}{|c|c|c|}
\hline No. crt. & Organochloride insecticide & Retention time (minute) \\
\hline 1. & HCB & 10.93 \\
\hline 2. & Lindane ( $-\mathrm{HCH})$ & 11.57 \\
\hline 3. & Heptachlor & 13.99 \\
\hline 4. & $\alpha-\mathrm{HCH}$ & 10.68 \\
\hline 5. & $\beta-\mathrm{HCH}$ & 11.43 \\
\hline 6. & $\delta$ - HCH & 12.32 \\
\hline 7. & Heptachlor-endo & 17.47 \\
\hline 8. & Heptachlor-exo & 17.24 \\
\hline 9. & $\alpha-$ endosulfane & 19.08 \\
\hline 10. & $\beta-$ endosulfane & 22.36 \\
\hline 11. & Endosulfan sulfate & 25.09 \\
\hline 12. & pp'- DDD & 23.19 \\
\hline 13. & pp'- DDT & 25.61 \\
\hline 14. & pp'- DDE & 20.62 \\
\hline 15. & op - DDT & 23.32 \\
\hline 16. & Alochlor & 13.93 \\
\hline 17. & Aldrin & 15.38 \\
\hline 18. & Dieldrin & 20.52 \\
\hline 19. & Endrin & 21.80 \\
\hline
\end{tabular}

Table 5. Retention time of organochlorine insecticides from mixture

Since at these retention times some interferences from also soil can occur, a second GC-MSD method has been tested, being reccomended and frequently used in pesticides residue analyses. In this context, standard solutions were prepared for 11 organochlorine insecticides in the range of $0.1-0.5 \mathrm{mg} / \mathrm{L}$ and were injected into GC-MS.

For the quantitative analysis of pesticide residues from stock solution of $1000 \mathrm{mg} / \mathrm{L}$ containing 19 organochlorine pesticides a set of intermediate solutions has been prepared having the following concentrations: $0.05 ; 0.1$ and $0.25 \mathrm{mg} / \mathrm{L}$. After injection into GC-MS autosampler the calibration curves for organochlorine insecticides were obtained.

Qualitative and quantitative determination of insecticides in water and plant samples is performed by GC-MS technique in the similar conditions as for soil sample analyses. 


\begin{tabular}{|c|c|c|c|}
\hline Nr. crt. & Organochloride insecticide & Retention time (minute) & Specific ions \\
\hline 1. & $\mathrm{HCB}$ & 9.61 & \\
\hline 2. & Lindan $($ ( $-\mathrm{HCH})$ & 10.41 & 181,219 \\
\hline 3. & Heptaclor & 12.25 & $337,237,194$ \\
\hline 4. & $\alpha-\mathrm{HCH}$ & 9.53 & 181,219 \\
\hline 5. & $\beta-\mathrm{HCH}$ & 9.63 & \\
\hline 6. & $\delta-\mathrm{HCH}$ & 11.40 & 181,219 \\
\hline 7. & Heptaclor-endo & 14.73 & $337,237,194$ \\
\hline 8. & Heptachlor-exo & 14.77 & \\
\hline 9. & $\alpha$ - endosulfan & 15.86 & $195,269,241,339$ \\
\hline 10. & $\beta$ - endosulfan & 17.65 & \\
\hline 11. & Endosulfansulfat & 19.36 & 272,289 \\
\hline 12. & pp'- DDD & 18.06 & $235,165,237$ \\
\hline 13. & $\mathrm{pp}^{\prime}-\mathrm{DDT}$ & 19.45 & $235,165,237$ \\
\hline 14. & $\mathrm{pp}^{\prime}-\mathrm{DDE}$ & 16.57 & \\
\hline 15. & op - DDT & 18.09 & \\
\hline 16. & Aloclor & 13.23 & \\
\hline 17. & Aldrin & 13.35 & $263,257,293,220$ \\
\hline 18. & Dieldrin & 16.78 & $263,277,345$ \\
\hline 19. & Endrin & 17.53 & $245,279,263,345$ \\
\hline
\end{tabular}

Table 6. Retention times and specific mass for ions detected

\begin{tabular}{|c|c|c|c|c|c|}
\hline \multicolumn{6}{|c|}{ Methods of organochlorine insecticides analyses } \\
\hline \multicolumn{2}{|r|}{ in SOIL } & \multicolumn{2}{|c|}{ from WATER } & \multicolumn{2}{|c|}{ from PLANTS } \\
\hline Extraction & Purification & Extraction & Cleaning & Extraction & Cleaning \\
\hline $\begin{array}{l}\text { Static extraction } \\
\text { - in a mixture of } \\
\text { acetone-hexane } \\
1: 1 . \\
\text { Dynamic } \\
\text { extraction } \\
\text { - a mixture of } \\
\text { acetone, } \\
\text { petroleum ether, } \\
\text { methylene } \\
\text { chloride } 1: 1: 1 .\end{array}$ & $\begin{array}{l}\text { For both extraction } \\
\text { methods the same } \\
\text { purification method } \\
\text { was used with } \\
\text { silicagel } 60 \text {, having } \\
\text { particle size of } 63-200 \\
\mu \mathrm{m} . \\
\text { The recovery rate of } \\
\text { first extraction } \\
\text { procedure is between } \\
40-60 \% \text {, and in the } \\
\text { dynamic extraction is } \\
\text { between } 70-90 \% .\end{array}$ & $\begin{array}{l}\text { with } \\
\text { petroleum } \\
\text { ether or } \\
\text { hexane } 5: 1 \\
\text { in water as } \\
\text { solvent. }\end{array}$ & $\begin{array}{l}\text { water being a } \\
\text { simple } \\
\text { matrix, there } \\
\text { is no need the } \\
\text { cleaning of } \\
\text { organic } \\
\text { extract. }\end{array}$ & $\begin{array}{l}\text { with } \\
\text { acetone/ } \\
\text { water 1:2. }\end{array}$ & $\begin{array}{l}\text { for plant } \\
\text { samples } \\
\text { the liquid- } \\
\text { liquid } \\
\text { cleaning } \\
\text { is enough. }\end{array}$ \\
\hline
\end{tabular}

Table 7. Multiresidual analysis methods for organochlorine analyses in soil water and plants 


\subsection{Organochlorine pesticide residues in soil and water}

\subsubsection{Transfer and translocation}

A study was performed in Arges River area, Romania, regarding the presence, persistency and accumulation of these organochlorine insecticides in surface water samples, underground water samples (drills), soil samples $(0-10 \mathrm{~cm} ; 10-20 \mathrm{~cm} ; 40-60 \mathrm{~cm}$ ) and vegetable plants (cabbage-fruit and tomatoes - for endosulfane).

Water samples extraction is done by direct contact with dichloromethane, after drying the sample with sodium sulfate hydricum. Cleaning was done on celite column with hexane.

In underground water samples very small concentration levels have been detected, below those which might affect the human health, as one can see in the following tables:

\begin{tabular}{|c|c|c|c|c|}
\hline Sample & Lindan & Aldrin & alfa-endosulfan & DDT \\
\hline P1 & 0.050 & 0.041 & 0.053 & 0.039 \\
\hline P2 & 0.054 & 0.033 & 0.153 & 0.053 \\
\hline P3 & 0.040 & 0.045 & 0.054 & 0.040 \\
\hline P4 & 0.042 & 0.014 & 0.080 & 0.065 \\
\hline
\end{tabular}

Table 8. Organochlorine concentration levels in surface water $(\mu \mathrm{g} / \mathrm{L})$

\begin{tabular}{|c|c|c|c|c|}
\hline Sample & Lindan & Aldrin & alfa-endosulfan & DDT \\
\hline P1 & 0.005 & 0.006 & 0.002 & 0.010 \\
\hline P2 & 0.007 & 0.008 & 0.009 & 0.012 \\
\hline P3 & 0.025 & 0.009 & 0.007 & 0.014 \\
\hline P4 & 0.023 & 0.004 & 0.005 & 0.011 \\
\hline
\end{tabular}

Table 9. Organochlorine concentration levels in undergroundwater $(\mu \mathrm{g} / \mathrm{L})$

\begin{tabular}{|c|c|c|c|c|c|}
\hline Sample & $\begin{array}{c}\text { Layer depth } \\
\mathbf{( c m )}\end{array}$ & Lindan & Aldrin & alfa-endosulfan & DDT \\
\hline \multirow{4}{*}{ P1 } & $0-10$ & 0.547 & 0.451 & 0.518 & 0.708 \\
& $10-20$ & 0.117 & 0.106 & 0.127 & 0.120 \\
& $20-40$ & 0.034 & 0.024 & 0.017 & 0.035 \\
& $40-60$ & nd & nd & nd & nd \\
\hline \multirow{3}{*}{ P2 } & $0-10$ & 0.551 & 0.442 & 0.500 & 0.665 \\
& $10-20$ & 0.112 & 0.113 & 0.114 & 0.127 \\
& $20-40$ & 0.032 & 0.027 & 0.028 & 0.032 \\
& $40-60$ & nd & nd & nd & nd \\
\hline
\end{tabular}




\begin{tabular}{|c|c|c|c|c|c|}
\hline Sample & $\begin{array}{c}\text { Layer depth } \\
(\mathbf{c m})\end{array}$ & Lindan & Aldrin & alfa-endosulfan & DDT \\
\hline \multirow{4}{*}{ P3 } & $0-10$ & 0.557 & 0.513 & 0.492 & 0.617 \\
& $10-20$ & 0.122 & 0.092 & 0.095 & 0.120 \\
& $20-40$ & 0.031 & 0.026 & 0.026 & 0.035 \\
& $40-60$ & nd & nd & nd & nd \\
\hline \multirow{4}{*}{ P4 } & $0-10$ & 0.572 & 0.468 & 0.506 & 0.649 \\
& $10-20$ & 0.118 & 0.092 & 0.088 & 0.111 \\
& $20-40$ & 0.029 & 0.031 & nd & 0.043 \\
& $40-60$ & nd & nd & nd & nd \\
\hline
\end{tabular}

nd - nedetectabil

Table 10. Organochlorine concentration levels in soil $(\mathrm{mg} / \mathrm{kg})$

\subsection{The accumulation of studied insecticides in vegetables as effect of treatments with endosulfane on soil and plants}

In order to follow the persistency and accumulation of endosulfane residues in cabbage and tomatoes controlled treatments with Thionex 3I CE have been applied in concentration of 0.2 $\mathrm{mg} / \mathrm{kg}$ for cabbage and tomatoes, 20 days before harvesting.

At each sampling period a number of 5 units of cabbage-fruit and $1 \mathrm{~kg}$ of tomatoes were taken. For each sampling period 3 samples were analysed, and average values are presented in the tables below.

\begin{tabular}{|c|c|c|}
\hline Days after treatment (no.) & $\begin{array}{c}\text { Residue în } \mathbf{~ m g} / \mathbf{k g} \\
\text { (average values) }\end{array}$ & $\begin{array}{c}\text { Residue în } \mathbf{~ m g} / \mathbf{k g} \\
\text { (average values) }\end{array}$ \\
\hline 3 & 5.42 & 5.42 \\
\hline 7 & 3.00 & 3.00 \\
\hline 14 & 1.70 & 1.70 \\
\hline 21 & 0.71 & 0.71 \\
\hline 28 & 0.44 & 0.44 \\
\hline 42 & $<0.025$ & $<0.025$ \\
\hline
\end{tabular}

Table 11. Degradation dynamics of endosulfane insecticide in cabbage and tomatoes

Treatments were applied to soil with Chinese cabbage and radish crops, in small plants phase, protected crops, in dose of $1.8 \mathrm{mg} / \mathrm{kg}$ (ppm) (lower dose) and $18 \mathrm{mg} / \mathrm{kg}$ (ppm) (upper dose). A chromatogram of a mixture of organo-chlorinated insecticides including endosulfan and its isomers has been registered.

Determination of endosulfane and its congeners content was done at harvest in leaves and root for radish, in fruit for cabbage and in soil. 


\begin{tabular}{|c|c|c|c|c|c|}
\hline \multirow{2}{*}{ Year } & \multirow{2}{*}{\multicolumn{2}{|c|}{ Doze (ppb) }} & \multicolumn{3}{|c|}{ Residue mg/kg } \\
\hline & & & $\alpha$-endosulfan & $\beta$-endosulfan & Endosulfan-sulfat \\
\hline \multirow{2}{*}{2003} & \multicolumn{2}{|c|}{$1800^{*}$} & $<0.50$ & $<0.50$ & 1.50 \\
\hline & \multicolumn{2}{|c|}{$18000^{* *}$} & 0.10 & 0.40 & nd \\
\hline \multirow{2}{*}{2004} & \multicolumn{2}{|c|}{1800} & $<0.50$ & $<0.50$ & 0.80 \\
\hline & \multicolumn{2}{|c|}{18000} & 0.10 & 0.40 & 3.40 \\
\hline \multirow{2}{*}{ Year } & \multirow{2}{*}{$\begin{array}{l}\text { Doze } \\
(\mathrm{ppb})\end{array}$} & accumulation & \multicolumn{3}{|c|}{ Residue mg/kg } \\
\hline & & \multirow{5}{*}{ leaves } & $\alpha$-endosulfan & $\beta$-endosulfan & Endosulfan-sulfat \\
\hline \multirow{2}{*}{2003} & 1800 & & $<1$ & $<1$ & $<1$ \\
\hline & 18000 & & 0.30 & 0.80 & nd \\
\hline \multirow{2}{*}{2004} & 1800 & & $<1$ & $<1$ & $<1$ \\
\hline & 18000 & & 0.10 & 0.20 & 3.60 \\
\hline \multirow[t]{2}{*}{ Year } & \multirow{2}{*}{$\begin{array}{l}\text { Doze } \\
(\mathrm{ppb})\end{array}$} & accumulation & \multicolumn{3}{|c|}{ Residue $\mathrm{mg} / \mathrm{kg}$} \\
\hline & & \multirow{5}{*}{ root } & $\alpha$ - endosulfan & $\beta$ - endosulfan & $\begin{array}{c}\text { Endosulfan- } \\
\text { sulfat }\end{array}$ \\
\hline \multirow{2}{*}{2003} & 1800 & & $<0.5$ & $<0.5$ & 2.00 \\
\hline & 18000 & & 0.20 & 1.40 & 20 \\
\hline \multirow{2}{*}{2004} & 1800 & & $<0.5$ & $<0.5$ & 1.30 \\
\hline & 18000 & & 0.10 & 0.50 & 14.60 \\
\hline
\end{tabular}

* $=1800$ ppb- lower doze; ${ }^{* *}=18000 \mathrm{ppb}$ - upper doze

Table 12. Concentration of endosulfane in cabbage and radish

Reffering to endosulfane accumulation at smaller dose there are no differences between the 3 congeners, both in leaves and in root. In case of upper dose it might be remarked the difference between the accumulation level in root comparing to the level from leaves.

The biggest amounts were detected in case of endosulfane-sulfate congener.

\begin{tabular}{|c|c|c|c|c|}
\hline \multirow{2}{*}{ Year } & \multirow{2}{*}{$\begin{array}{c}\text { Dose } \\
\text { (ppb) }\end{array}$} & \multicolumn{3}{|c|}{ Residue $\mathbf{~ m g} / \mathbf{k g}$} \\
\cline { 3 - 5 } & $1800($ low) & $\alpha$-endosulfan & $\beta$-endosulfan & Endosulfan-sulfat \\
\hline 2003 & 1800 & 1.8 & 58.3 & 323.5 \\
\hline 2004 & \multirow{3}{|c|}{ Residue $\mathbf{~ m g / k g}$} \\
\hline \multirow{2}{*}{ Year } & \multirow{2}{*}{$\begin{array}{c}\text { Dose } \\
\text { (ppb) }\end{array}$} & $\alpha$-endosulfan & $\beta$ - endosulfan & Endosulfan-sulfat \\
\cline { 3 - 5 } & $18000($ high) & 21.60 & 209.60 & 820.30 \\
\hline 2003 & 18000 & 20.10 & 230.60 & 1049.80 \\
\hline
\end{tabular}

Table 13. Persistency of endosulfane residue in soil cultivated with cabbage and radish

Accumulation level of endosulfane insecticide in the cabbage soil crop was surveyed only at lower dose, while for radish crop only at higher dose. The results show for cabbage crop the presence in quantifiable levels of all 3 congeners. 
These results indicate the necessity of a very good control on long persistency pesticide use. The most frequent cases of environmental factors pollution are are caused by ignorance, negligence and improper use of pesticides.

The results show that the accumulation of these pollutants in soil, plants and underground waters is influenced by chemical structure of compound, and physico-chemical properties of soil as well.

The monitoring of organochlorine insecticide residues in soil and water was carried out in samples from the same area. The distribution of organochlorine insecticide residues in the four soil layers is different, in the upper layer being more than $80 \%$ from total toxic content, while for the last layer the toxic values are below detection limit.

Determination made for persistency and accumulation level in different vegetables of organochlorine insecticide residues of endosulfane type indicate preferential accumulation in root and less in leaves.

\section{Use of chemical and biochemical sensors for analytical control of pollutants}

Enzymatic systems were used to determine pesticide content based on cholinesterase. A set of chemical and biochemical sensors has been achieved and tested in the presence of organic solvents for analytical control of pollutants in environmental samples. Operational parameters of biosensors have been optimized for the determination of organophosphorus insecticides and a method for preconcentration and oxidation of insecticides has been developed.

\subsection{Determination of organophosphorus insecticides using a potentiometric biosensor based on acetylcholinesterase (AChE)}

Two organophosphorus compounds have been determined using a potentiometric reusable biosensor. Acetylcholinesterase (AChE) was immobilized on a cellulose ester membrane, using for this purpose glutaraldehyde and bovine serum albumin (BSA). The membrane was then fixed on a flat surface glass electrode. The degree of inhibition of the enzyme is dependent on the concentration of pesticide in the sample. Inhibited enzyme was reactivated using pyridine-2-aldoxime metyliodide (2-PAM).

AChE catalyzes the hydrolysis reaction of the substrate, acetylcholine, to obtain as reaction products choline and acetic acid.

The latter produces a $\mathrm{pH}$ variation of membrane solution, which is measured using a glass electrode. When insecticides inhibit the enzyme immobilized on the membrane one can be seen a reduction in variation of $\mathrm{pH}$ in the presence of substrate.

This biosensor based on AChE immobilized on a cellulose ester membrane has a good operational and storage stability. Organophosphorus insecticides used in these experiments 
were: ethyl paraoxon and dichlorvos. After each measurement of enzyme inhibition, reactivation of the enzyme biosensor was made by incubating for $10 \mathrm{~min}$ in a solution of 2PAM $0.02 \mathrm{~mol} / \mathrm{L}$ prepared in $0.002 \mathrm{M}$ phosphate buffer, $\mathrm{pH}=8$. Comparing the percentages of inhibition obtained at the same concentrations of paraoxon, dichlorvos it was found a greater capacity of enzyme inhibition of paraoxon than of dichlorvos.

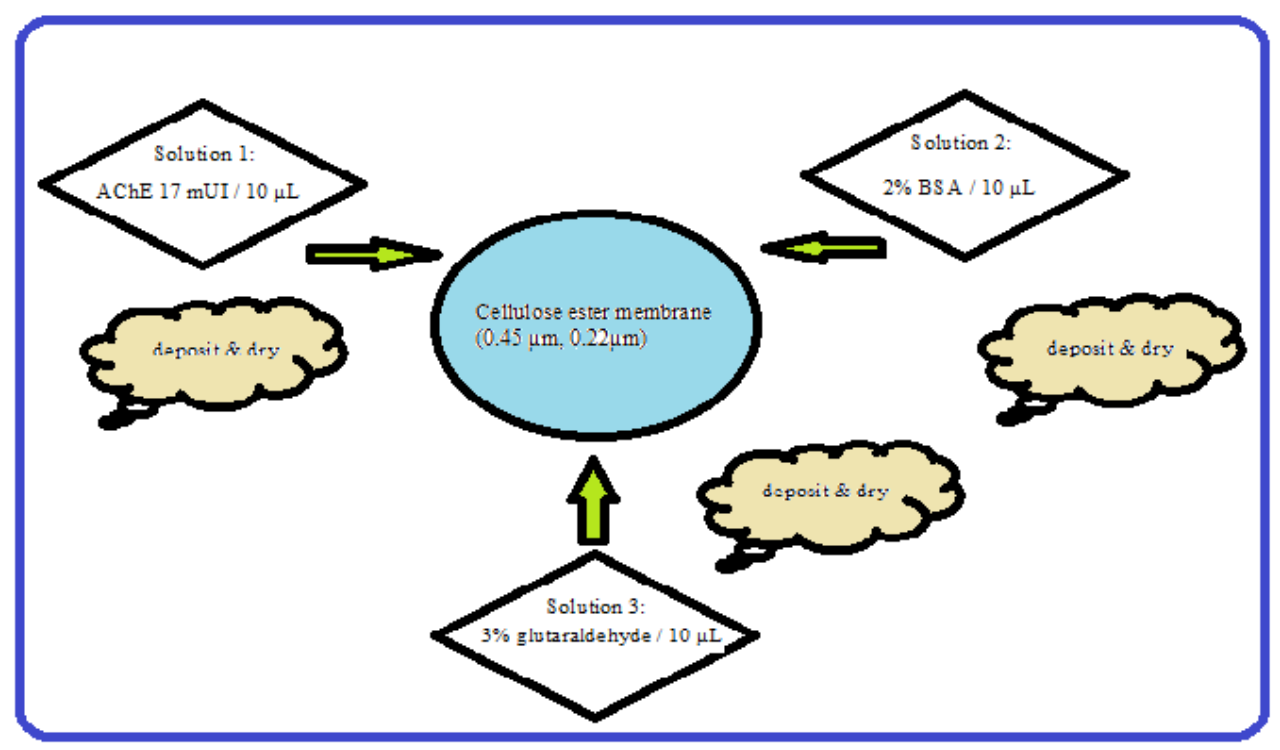

Figure 5. AChE immobilization on cellulose ester membrane

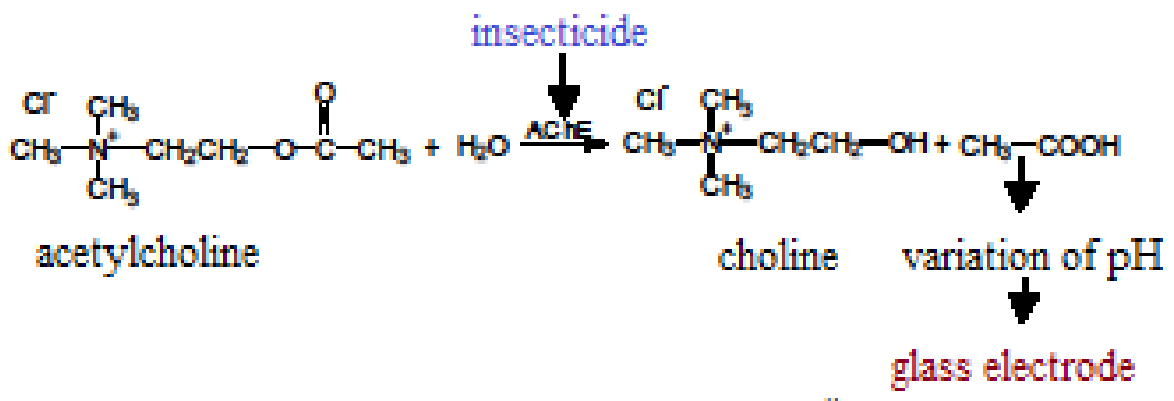

Scheme 1. The principle of potentiometric detection of organophosphorus insecticides using a biosensor with $\mathrm{AChE}$

The detection limit obtained with biosensors built was $0.5 \mu \mathrm{M}$ for dichlorvos and $0.1 \mu \mathrm{M}$ for ethyl paraoxon. This method requires no sample pre-treatments and biosensor can be easily used to identify and evaluate the toxicity of samples analyzed. 


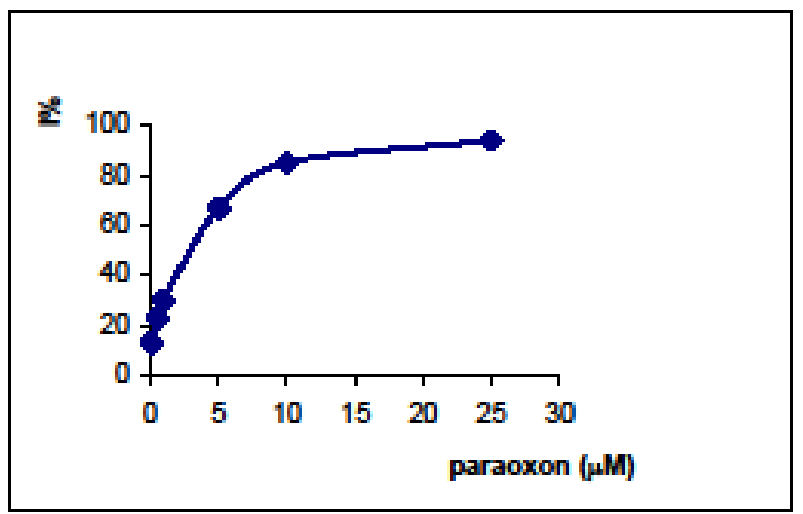

Working conditions: $0.002 \mathrm{M}$ phosphate buffer plus $0.1 \mathrm{M} \mathrm{KCl}, \mathrm{pH}=8 ; 17 \mathrm{mUI}$ AChE/membrane, incubation for 20 minutes.

Figure 6. Inhibition curve of the biosensor based on AChE for paraoxon

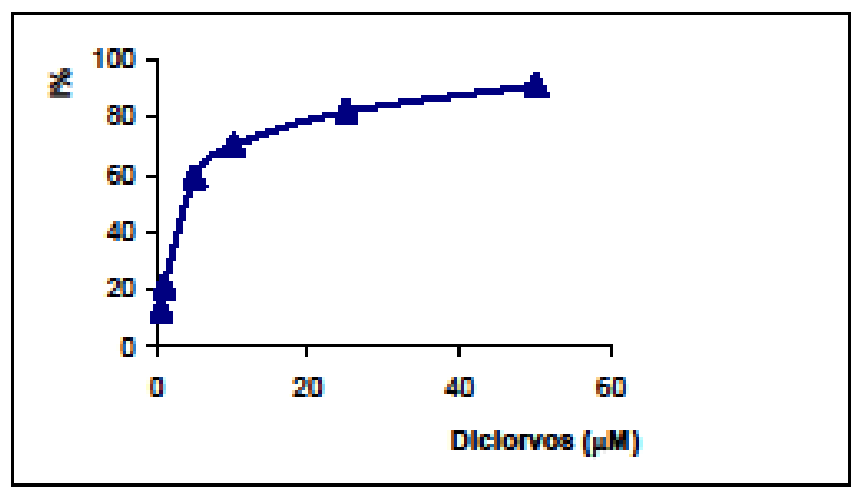

Working conditions: $0.002 \mathrm{M}$ phosphate buffer plus $0.1 \mathrm{M} \mathrm{KCl}, \mathrm{pH}=8 ; 17 \mathrm{mUI}$ AChE/membrane; incubation for 20 minutes.

Figure 7. Inhibition curve based on AChE biosensor for dichlorvos

\subsection{Immobilisation of acetylcholinesterase (AChE) using sol-gel process}

AChE immobilization was followed in sol-gel matrix to achieve an amperometric biosensor for the detection of organophosphorus insecticides. We optimized conditions for immobilization of AChE in sol-gel matrix for amperometric biosensor development of the mediator tetracianochinodimetan (TCNQ). Two types of precursors have been used: tetrametoxi silan - TMOS, and metyl tetrametoxisilan - MTMOS.

Sol-gel solution was obtained by mixing TMOS and MTMOS precursors with $1 \mathrm{mM} \mathrm{HCl}$ solution, PEG600 and water. The resulting mixture was 20 minutes sonicated for homogenization and then kept at $40^{\circ} \mathrm{C}$ for 12 hours before use, in order to assure silane 
hydrolysis. From these experiments the optimal composition of the sol-gel matrix for AChE immobilization has been established.

\begin{tabular}{|c|c|c|c|c|}
\hline \multicolumn{5}{|c|}{ Sol-gel } \\
\hline TMOS & MTMOS & $\mathrm{H}_{2} \mathrm{O}$ & $\mathrm{HCl}$ & PEG600 \\
\hline $20 \mu \mathrm{l}$ & $10 \mu \mathrm{l}$ & $44 \mu \mathrm{l}$ & $40 \mu \mathrm{l}$ & $5 \mu \mathrm{l}$ \\
\hline
\end{tabular}

Table 14. Composition optimal sol-gel

\begin{tabular}{|c|c|c|}
\hline \multicolumn{3}{|c|}{ Sensitive layer } \\
\hline Enzyme solution & Sol-gel & $\begin{array}{c}\text { Graphite power with } \\
\text { TCNQ + 3\% HIEC }\end{array}$ \\
\hline $25 \mu \mathrm{l}$ & $25 \mu \mathrm{l}$ & $25 \mu \mathrm{l}$ \\
\hline
\end{tabular}

Table 15. Composition optimal for submitting sensitive layer

Determination of immobilized enzyme activity, and inhibition tests were performed by amperometric measurements in a cell with a volume of $10 \mathrm{~mL}$. Screen-print electrodes were modified with an electrochemical mediator sensitive for the oxidation of thiol compounds, TCNQ, which allows measurements at low potential.

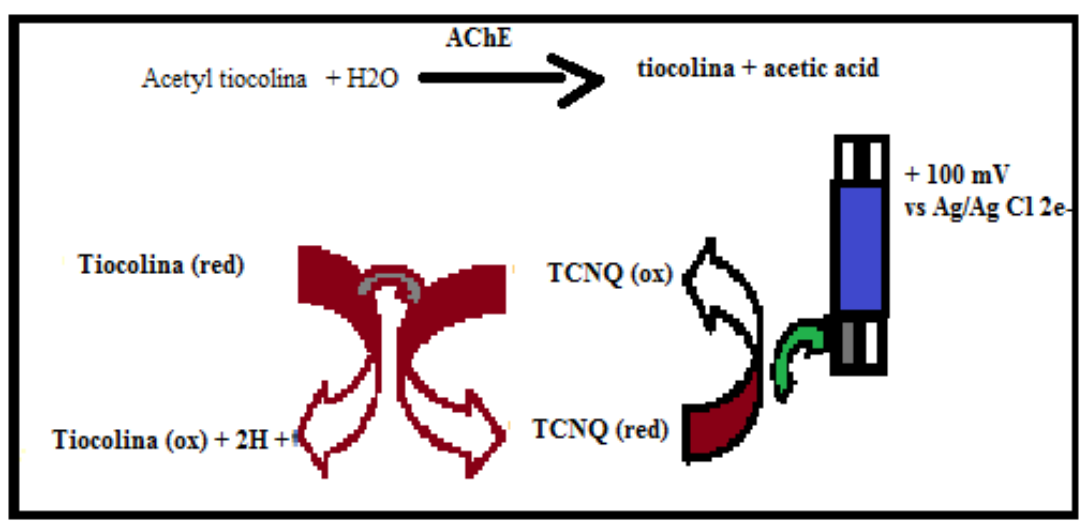

Figure 8. Amperometric detection of tiocoline produced in the enzymatic hydrolysis of acetiltiocoline

For detection of insecticides, inhibition measurements were performed in three stages:

i. Measuring the initial biosensor response to acetiltiocoline injection and averaging the results obtained;

ii. Sensor incubation for 10 or 20 minutes into insecticide solution;

iii. Measuring the residual response and averaging the results obtained.

Percent inhibition is calculated as:

$$
\mathrm{I} \%=\left(\mathrm{I}_{0}-\mathrm{I}\right) / \mathrm{I}_{0} \times 100
$$


where: $\mathrm{I} \%=$ percentage of inhibition; $\mathrm{I}_{0}=$ current value before inhibition; $\mathrm{I}=$ current value after inhibition.

For immobilization of AChE different mixtures of TMOS, MTMOS, PEG600, $1 \mathrm{mM} \mathrm{HCl}$ and $\mathrm{H}_{2} \mathrm{O}$ have been tested for obtaining hydrolysated precursors. In this way the operational stability of biosensors has been studied.

To prepare the sensitive layer of biosensors the following mixtures of reagents were used: (i) graphite powder with TCNQ in HEC, (ii) AChE in buffer and (iii) precursor hydrolysated.

Another feature studied was storage stability of the biosensors with enzyme immobilized in sol-gel. Good results were obtained by biosensors conservation in freezer at a temperature of $-20^{\circ} \mathrm{C}$ in vacuum.

The influence of substrate concentration on the biosensor response has been also studied. Substrate concentration chosen for measurements of enzyme activity was $1 \mathrm{mM}$. For inhibition tests three insecticides have been used: paraoxon as reference insecticide, oxon clorpirifosmetyl as one of the most toxic insecticides and dichlorvos.

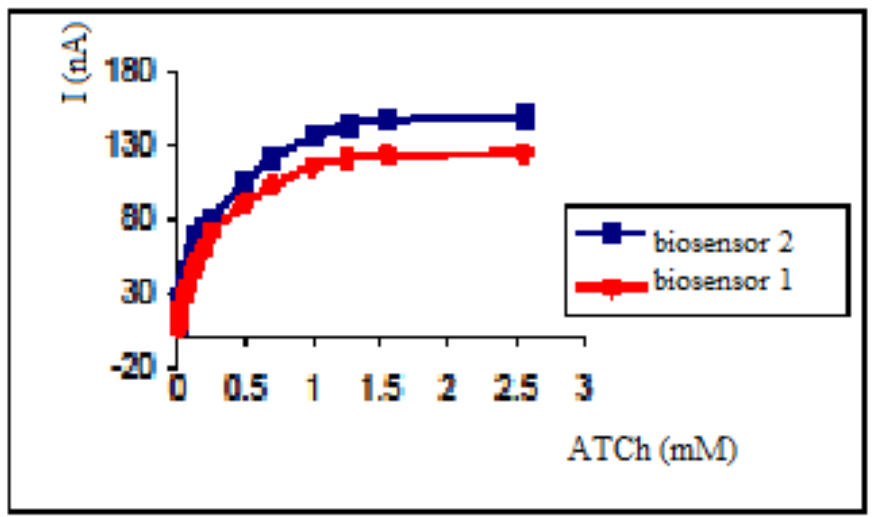

Figure 9. Influence of substrate concentration on the biosensor response based on AChE

Working conditions: $0.1 \mathrm{M}$ phosphate buffer plus $0.1 \mathrm{M} \mathrm{KCl}, \mathrm{PH}=8.2 \mathrm{mUI} / \mathrm{AChE} /$ electrode, $100 \mathrm{mV}$ vs $\mathrm{Ag} / \mathrm{AgCl}$.

For each of biosensors a decrease of signal after incubation phase could be observed which implies a decrease in AChE activity immobilized on the electrode.

Inhibition curves are presented for the three insecticides using the two biosensors 1 and 2 .

The best results were obtained with the biosensor 2 for the incubation time of 20 minutes. For paraoxon was obtained a detection limit of $0.008 \mu \mathrm{M}$.

In case of dichlorvos a detection limit of $0.02 \mu \mathrm{M}$ was obtained.

The best limit of detection was obtained for chlorpyrifos-methyl Oxon, i.e. $0.001 \mu \mathrm{M}$. 


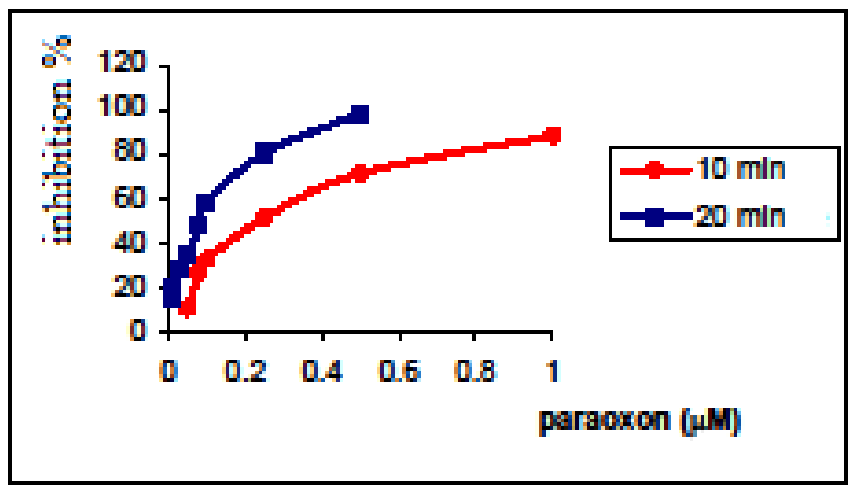

Figure 10. Influence of paraoxon concentration on first biosensor response with $\mathrm{AChE}$ immobilized in sol-gel; each experimental point is the average of 3 measurements

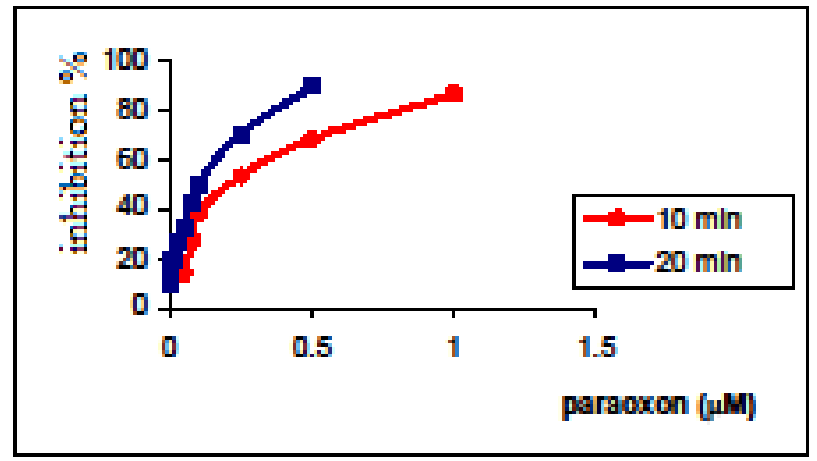

Figure 11. Influence of paraoxon concentration on the second biosensor response with AChE immobilized in sol-gel

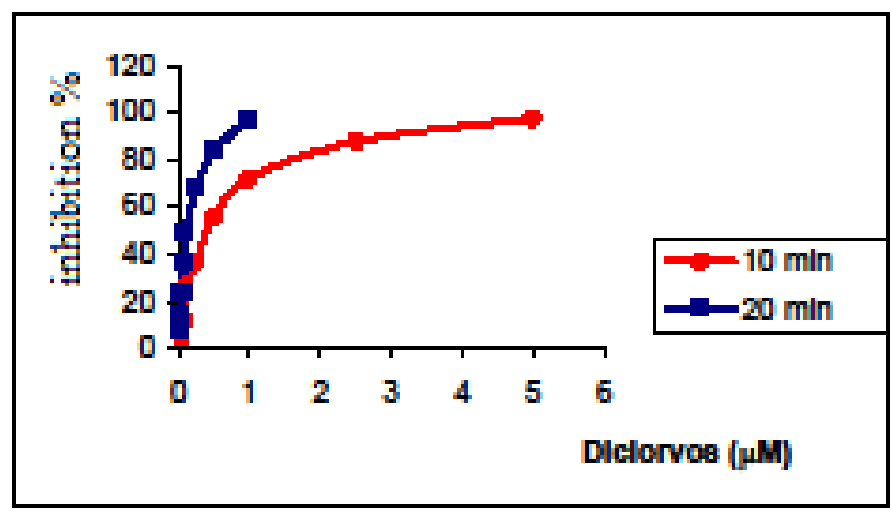

Figure 12. Influence of the concentration of dichlorvos on type 1 response with $\mathrm{AChE}$ biosensor immobilized in sol-gel, each experimental point is the average of 3 measurements. 


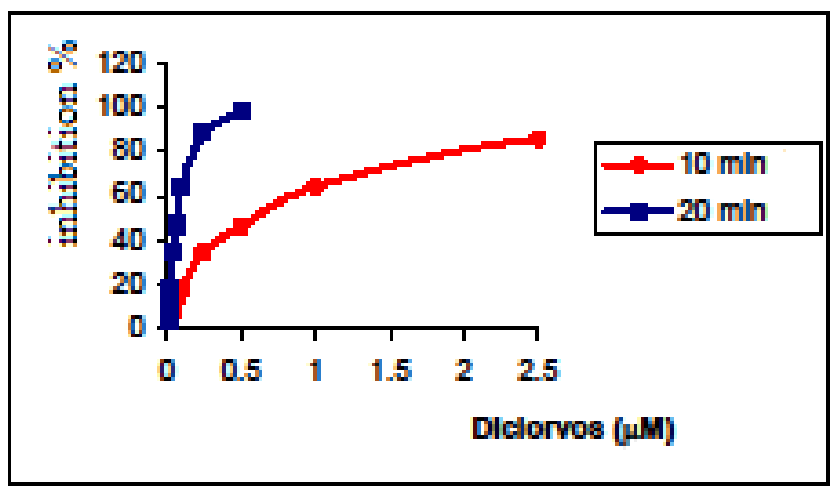

Figure 13. Influence of dichlorvos concentration on second type biosensor response with AChE immobilized in sol-gel

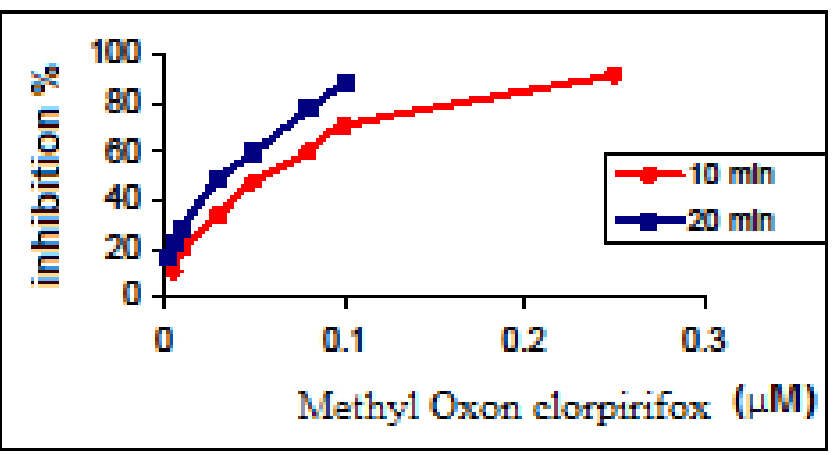

Figure 14. Influence of the concentration of chlorpyrifos methyl Oxon on the biosensor response with AChE immobilized in sol-gel

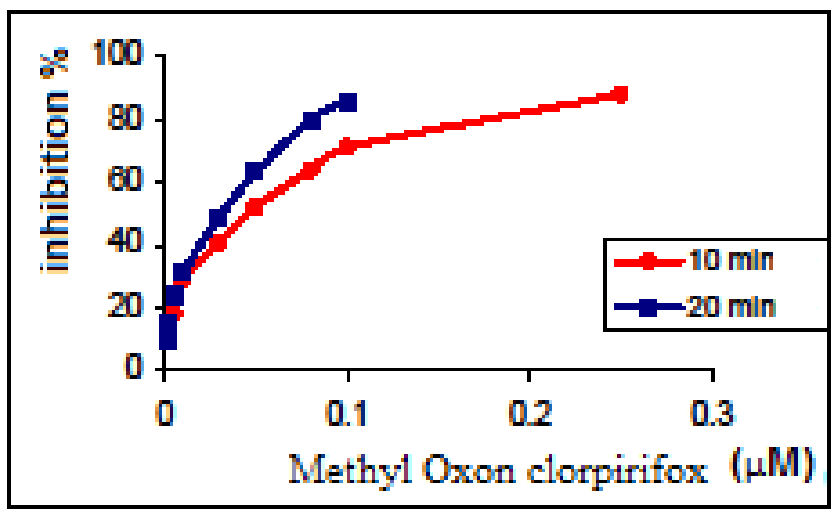

Figure 15. Influence of the concentration of chlorpyrifos methyl 2 Oxon on biosensor 2 response with AChE immobilized in sol-gel 
Comparing the percentages of inhibition obtained at the same concentrations of paraoxon, dichlorvos and chlorpyrifos-methyl Oxon a greater capacity of enzyme inhibition was found for chlorpyrifos methyl Oxon, followed by paraoxon and dichlorvos.

\subsection{Preconcentration and oxidation of organophosphorus insecticides}

To improve detection limits and selectivity of analyzes performed with biosensors a column containing XAD2 has been used. In this way organophosphorus insecticides can be preconcentrate and oxidized. Solid phase extraction is widely used to determine insecticides, so this method can be also adopted for biosensors, provided that the organic solvent used in elution insecticide to be compatible with the enzyme and the transducer. Depending on the hidrofobicity of organic solvent and possible restraining effect of immobilization method on the enzyme, enzyme activity can be strongly affected. This is the reason for which the enzyme was immobilized in an optimized sol-gel matrix.

The biosensor thus o optimized shows good operational stability. The average response of a single biosensor was $245 \mathrm{nA}$ with good reproducibility of the biosensor response.

Biosensor response increases with increasing substrate concentration until a plateau (saturation of the enzyme). The influence of biosensor incubation in phosphate buffer solution (PBS) containing organic solvents has been also investigated as function on substrate concentration. For each graph different biosensors have been used.

The diagrams obtained at biosensors incubation for $10 \mathrm{~min}$ in PBS containing $10 \%$ ACN, methanol and ethanol do not show significant changes compared with the pattern obtained with the biosensor that was not in contact with organic solvents (Fig. 16).

The effect of the organic solvent on AChE activity has been studied by incubating the biosensor for 10, 15, and 20 minutes in $0.1 \mathrm{M}$ phosphate buffer solution containing $5,10,15 \%$ (v/v) ACN, ethanol and methanol (Fig. 17). It was found that the effect of distortion of the enzyme denaturation increases with time of biosensor incubation.

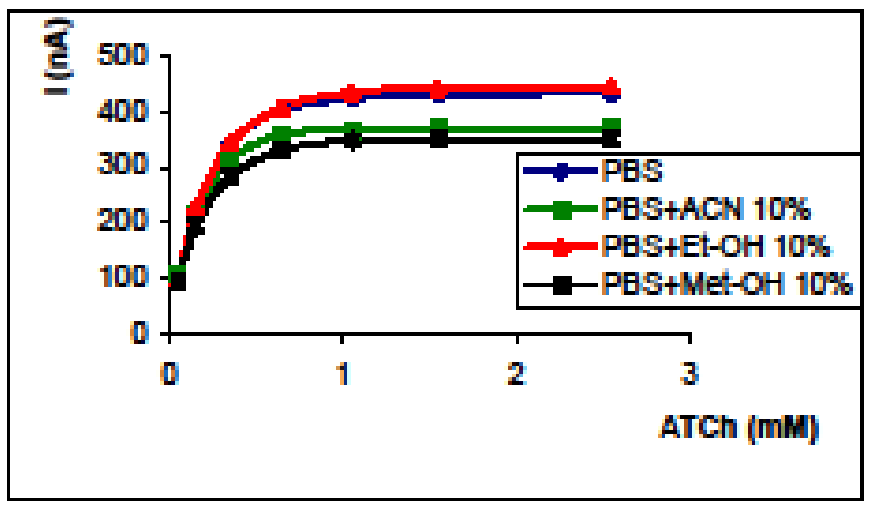

Figure 16. Effect of biosensor incubation in $0.1 \mathrm{M}$ PBS containing $10 \% \mathrm{ACN}, 10 \% \mathrm{Et}-\mathrm{OH}$ and $10 \%$ Met$\mathrm{OH}$ on calibration curve for ATCh 
Working conditions: phosphate buffer (PBS) $0.1 \mathrm{M} \mathrm{KCl}$ plus $0.1 \mathrm{M} ; 2 \mathrm{mUI}$ AChE / electrode, applied potential $100 \mathrm{mV}$ vs. $\mathrm{Ag} / \mathrm{AgCl}$, incubation time 10 minutes.

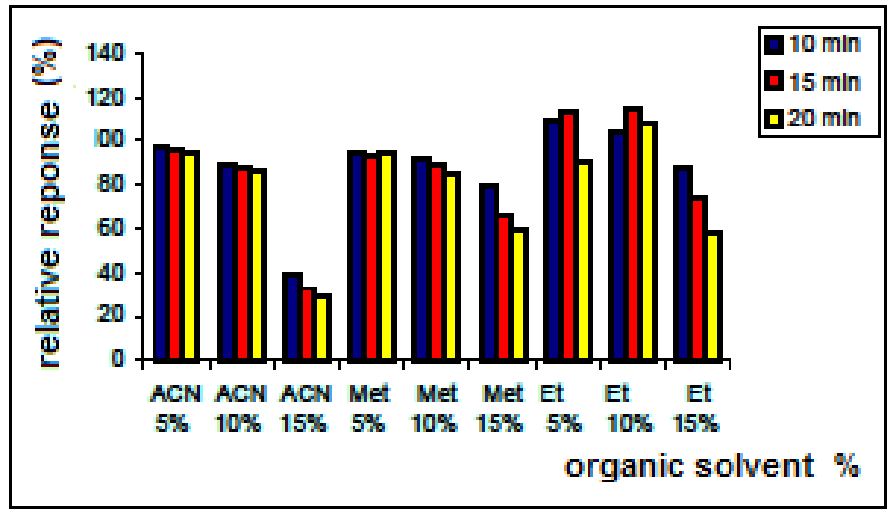

Figure 17. The effect of organic solvent $(\%, v / v)$ and incubation time on biosensor response. (ACN: acetonitrile; Met: methanol, Et: ethanol).

Working conditions: $0.1 \mathrm{M}$ phosphate buffer, $\mathrm{pH} 8,0.1 \mathrm{M} \mathrm{KCl} ; 1 \mathrm{mM}$ ATCh, applied potential: $+100 \mathrm{mV}$ vs $\mathrm{Ag} / \mathrm{AgCl}$; results are the average of three independent measurements.

For the incubation time of the biosensor of 10 minutes in phosphate buffer solution containing $5 \%(\mathrm{v} / \mathrm{v})$ organic solvent, the percentage change of enzyme activity is less than $10 \%$ and for this reason it was considered that the presence of organic solvent has no significant effect on AChE.

\begin{tabular}{|c|c|c|}
\hline Insecticides & $\begin{array}{c}\text { Concentration of } \\
\text { insecticides }\end{array}$ & RSD \\
\hline Paraoxon in PBS & $5 \times 10^{-7}$ & $\begin{array}{c}6,3 \% \\
(63 \pm 4 \% \text { inhibition, } \mathrm{n}=5)\end{array}$ \\
\hline $\begin{array}{c}7,4 \% \\
5 \% \text { (v/v)ACN }\end{array}$ & $5 \times 10^{-7}$ & $\begin{array}{c}11,7 \% \\
(43.2 \pm 3 \% \text { inhibition, } \mathrm{n}=5)\end{array}$ \\
\hline $\begin{array}{c}\text { Paraoxon after } \\
\text { preconcentration }\end{array}$ & $2.5 \times 10^{-7}$ & $\begin{array}{c}8,4 \% \\
(60 \pm 7 \% \text { inhibition, } \mathrm{n}=5)\end{array}$ \\
\hline Diclorvos in PBS & $2.5 \times 10^{-7}$ & $\begin{array}{c}9,5 \% \\
(32.3 \pm 2,7 \% \text { inhibition, } \mathrm{n}=5)\end{array}$ \\
\hline Diclorvos in 5\% (v/v) ACN & $2.5 \times 10^{-7}$ & $\begin{array}{c}11 \% \\
(20 \pm 1,9 \% \text { inhibition, } \mathrm{n}=5)\end{array}$ \\
\hline $\begin{array}{c}\text { Diclorvos after } \\
\text { preconcentration }\end{array}$ & $2.5 \times 10^{-7}$ & $(55.6 \pm 1 \%$ inhibition, $\mathrm{n}=5)$ \\
\hline
\end{tabular}

Table 16. Reproductibility of biosensor during inhibition tests 
The recovery studies of paraoxon and dichlorvos insecticides adsorbed on the column containing XAD2 were made according to the following steps:

i. Passage of the paraoxon /dichlorvos solution through the column;

ii. Elution with organic solvent of the insecticide retained on the column;

iii. Fraction collection and solution analysis.

Eluted fractions were diluted in PBS and then analyzed with AChE biosensors. It was found that on the use of $A C N$, the first eluted fraction was sufficient to remove the insecticides adsorbed, while larger volumes of solvent were required for ethanol (two fractions) and methanol (three fractions). Considering these results, ACN was chosen for XAD2 column elution of insecticides adsorbed. Concentration of $5 \%(\mathrm{v} / \mathrm{v}) \mathrm{ACN}$ was chosen as the optimal incubation environment.

Three diagrams were obtained for inhibition of dichlorvos and paraoxon on the following working conditions:

i. Incubation of the biosensor in $0.1 \mathrm{MPBS}, \mathrm{pH}=8$;

ii. Incubation of the biosensor in PBS containing 5\% (v/v) $\mathrm{ACN}$ to observe its sensitivity reduction due to organic solvent.

After the sample preconcentration on XAD2 column, the first elution fraction from the column was diluted with phosphate buffer, divided in two portions, and analyzed with the two different biosensors.

The inhibition diagrams obtained (Fig. 18 and Fig. 19) show a similar behaviour. The inhibition percentages increase with insecticide concentration until a plateau is reached. The difference between the percentages of inhibition of paraoxon and diclorvos is caused by different net toxicity of these insecticides on AChE.

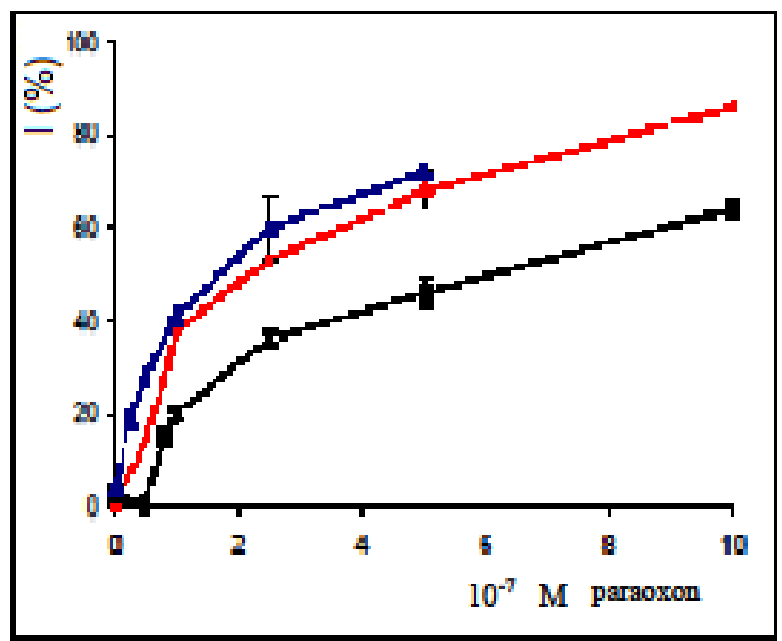

Figure 18. Inhibition curves obtained with the biosensor for paraoxon with AChE immobilized in solgel after 10 minutes of incubation in phosphate buffer, phosphate buffer with $5 \%$ (v/v) CAN 


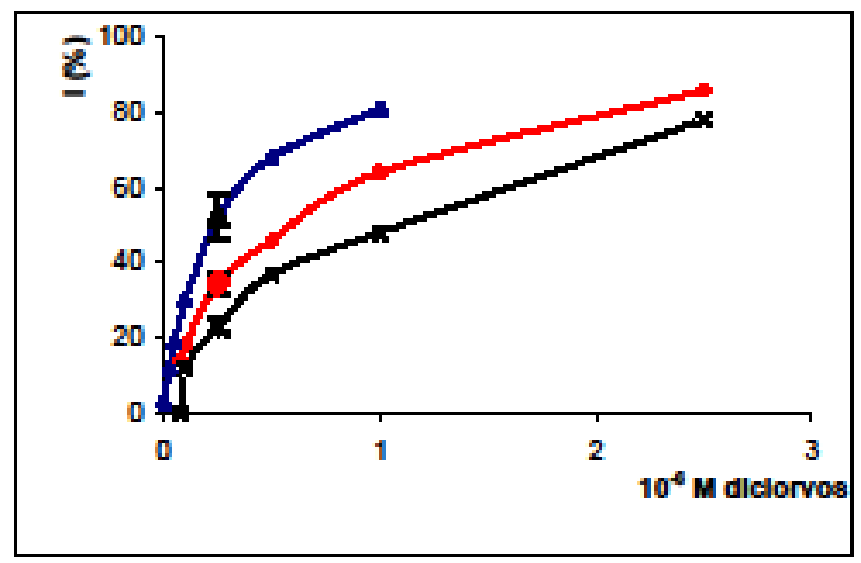

Figure 19. Inhibition curves for dichlorvos obtained with AChE biosensors immobilized in sol-gel after 10 minutes incubation in phosphate buffer, phosphate buffer with $5 \%(\mathrm{v} / \mathrm{v}) \mathrm{ACN}$.

The results are obtained from analysis of the first fraction $(0.5 \mathrm{~mL})$ eluted from the XAD2 column with ACN where the insecticide was preconcentrated. Fraction eluted in ACN was diluted to $10 \mathrm{~mL}$ with phosphate buffer.

For paraoxon, the calibration curve obtained in PBS is linear up to $10^{-7} \mathrm{M}$ with a detection limit of $5 \times 10^{-8} \mathrm{M}$. Small inhibitory effect of acetonitrile and reduction of inhibition measured with biosensor incubated in $5 \%(\mathrm{v} / \mathrm{v}) \mathrm{ACN}$ is visible at low concentrations of insecticide. The inhibition curve obtained after passage of standard insecticide solutions through the column was linear between $2.5 \times 10^{-8}$ (detection limit) and $2.5 \times 10^{-7} \mathrm{M}$.

The results are obtained from analysis of the first fraction eluted with $0.5 \mathrm{~mL}$ of ACN on XAD2 column where the insecticide was preconcentrated. Fraction eluted in ACN was diluted to $10 \mathrm{~mL}$ with phosphate buffer.

For dichlorvos, the inhibition curve in PBS is linear from $8 \times 10^{-8}$ (detection limit) up to $2.5 \times 10^{-7} \mathrm{M}$. In case of biosensor incubation in standard solutions of dichlorvos prepared in PBS containing $5 \%(\mathrm{v} / \mathrm{v}) \mathrm{ACN}$, the graph is linear between $10^{-7}$ (detection limit) and $5 \times 10^{-7}$ M.

Using preconcentration stage allows produce a calibration curve at lower concentrations the linear part of which is between $2.5 \times 10^{-8} \mathrm{M}$ (detection limit) and $2.5 \times 10^{-7} \mathrm{M}$.

Thus the detection limit for paraoxon and dichlorvos was improved from $5 \times 10^{-8}$ and $8 \times 10^{-8} \mathrm{M}$ for inhibition measurements conducted in buffer at $2.5 \times 10^{-8}$ and $2.5 \times 10^{-8} \mathrm{M}$ after using preconcentration phase.

The method allows detection of organofosforotionate insecticides $(\mathrm{P}=\mathrm{S})$ by their oxidation to Oxon form $(\mathrm{P}=\mathrm{O})$ which is more toxic. 
Heterogeneous oxidation of insecticides was performed using methyl parathion oxidized to methyl paraoxon. Studies performed on biosensors based on AChE inhibition by methyl paraoxon obtained by heterogeneous oxidation of methyl parathion were compared with inhibition studies performed with standard solutions of ethyl paraoxon. This comparison was performed to estimate the effectiveness of oxidation of methyl parathion and denaturating effect of the enzyme produced by the reagent used for oxidation.

Oxidation of organofosforotionate compounds was performed in heterogeneous system. Preliminary studies were conducted to investigate and find the optimal parameters able to minimize the negative effect of the oxidant on the biosensor.

\section{Conclusion}

The goal of sustainable development is achievable in terms of counteracting the global challenges that humanity must face. These challenges that reinforce each other are: climate change, severe restriction of species biodiversity, including the default value of genetic resources, not fully explored, degradation processes, diminishing freshwater resources, soil erosion and sustainability of life support, the universal generator of food for all livings.

Research topics addressed in this context are part of the suite of scientific research conducted in European and world community regarding the action on the environment of pesticides used in agriculture. Moreover, the research results obtained are turned into account by offering the base of the evaluation of the social and economical impact on the environment and life quality.

\section{Author details}

Adriana MarianaBorş, Irina Meghea and Alin Gabriel Borş

National Institute for Research \& Development in Environmental Protection, Faculty of Applied Sciences, University POLITEHNICA of Bucharest, Romania

\section{References}

Andrews, S.S.; Flora, C.B., Mitchell, J.P. \& Karlen, D.L. (2003). Growers perception and acceptance of soil quality indices, Geoderma Vol. 114, 3-4, pp. (187-213).

Bors, A.M.; Lesnic, M., Meghea, A. \& Popa,I. (2009). Priority for development climate change action plan, International Symposium Environment and Industry - SIMI ECOIND, Bucharest.

Borş, A.M.; Lesnic, M., Meghea, A., (2008). Monitoring of emissions of POPs to reduce environmental impact, Ed. PRINTECH, ISBN 978-606-521-178-0, Bucharest.

Brady, N.C. \& Weil, R.R. (2002). The Nature and Properties of Soils, $13^{\text {th }}$ ed. Pearson Education 
Bucur, B.; Andreescu, S. \& J.-L. Marty (2004). Affinity Methods to Immobilize Acetylcholinesterases for Manufacturing Biosensors, Anal. Lett, Vol.37, No.8, pp. (15711588).

Bucur, B.; Danet, A. F. \& Marty J.L. (2004).Versatile method of cholinesterase immobilisation via affinity bonds using Concanavalin A applied to the construction of a screen-printed biosensor, Biosens. \& Bioelectr., Vol. 20, No.2, pp. (217-225).

Bucur, B.; Danet, A. F. \& Marty J.L. (2005). Cholinesterase immobilisation on the surface of screen-printed electrodes based on Concanavalin A affinity, Anal.Chim. Acta, Vol. 530, No.1, pp. (1-6).

Bucur, B.; Dondoi, M., Danet, A. F. \& Marty J.L. (2005). Insecticide identification using a FIA system with biosensors based on various cholinesterases, Anal. Chim. Acta, Vol. 539, pp. (195-201).

Bucur, B.; Fournier, D., Danet, A. F. \& Marty J.L., (2006). Biosensors based on highly sensitive acetylcholinesterases for enhanced carbamate insecticides detection, Anal. Chim. Acta, Vol. 562, No.1, pp. (115-121).

Crăciun, C.; Mocanu, V. \& Dumitru, S. (2004). Mineralogy and soil quality, Soil Science, Vol. XXXVIII, No.1-2, pp. (123-145).

Dăneț, A. F.; Neagu, D., Dondoi, M. P. \& Iliescu, N. (2004). Journal of Chemistry, Vol. 55, No. 1, pp. (1-10).

DeKimpe, C. (2002). Soil functions in managed ecosystems: the need for a balance. Trans 17th World Cong Soil Sci Bangkok Sym 65.

DeKimpe, C.R.\& Prasittiketlh, J. (2002). Soil indicators for sustainable land use, Trans $17^{\text {th }}$ World Cong Soil Sci Sym 32.

Dondoi, M. P. et. al. (2006), Organophosphorous insecticides extraction and oxidation on column for analysis with acetylcholinesterase (AChE) biosensor, Anal. Chim. Acta, Vol. 578, No.2, pp. (162-169).

Dumitru, E. et al. (2005). Soil conservation work between tradition and perspective in sustainable agriculture, Ed. Estfalia, Bucharest.

Florea N. (2003). Degradation and improve soil and land protection, Bucharest, pp. (310).

Florea, N. \& Ignat, P. (2007). About soil quality and its assessment, Forests Journal, No.4, pp. (122).

Greytak, A.B., et al., (2004). Appl.Phys.Lett. Vol. 84, No.21, pp. (4176).

Gruner, G. (2006), Anal Bioanal Chem 384, pp. (322-335).

Kolberg, I. Diana et .al. (2011). Development of a fast multiresidue method for the etermination of pesticides in dry samples (wheat grains, flour and bran) using QuEChERS based method and GC-MS, Food chemistry, Vol. 125, pp. (1436-1442).

Meghea, I. \& Borş, A.M. (2011) Trends and challenges in the new modern society, sustainable and inclusive, Ed. PRINTECH, ISBN 978-606-521-628-0, Bucharest.

Neamtu, C.S.; Ştefan, S. \& Borş, A.M. (2010). Transfer and translocation of organochlorine pesticide residues in an agricultural area of Romania, International Journal of Environment and Waste Management, Vol. 5, No.1-2, ISSN 1478-9876, pp. (114-124). 
Neamţu, S.; Borş, A.M \& Ştefan, S. (2007). Risk Assessment of some persistent organic pollutants on environment and health, Journal of Chemistry, Vol. 58, No. 9,- Prize CNCSIS in February 2008, pp. (938-942).

Wan, Q., et al., (2004). Apply Phys. Lett., Vol. 84, No. 18, pp. (3654).

Whang, D., et al. , (2004). Jpn. J. Appl. Phys., Vol. 43, No. 7B, pp. (4465).

Zheng G., et al., (2004) adv. Mater., Vol. 16, No. 21, pp. (1890). 